\title{
CORRECTIONS
}

\section{What can we learn from asthma in elite athletes?}

This Feature by Sophie Arie (BMJ 2012;344:e2556, doi:10. $1136 /$ bmj.e2556) incorrectly stated that asthma is not a "life threatening" condition.
Cite this as: BMJ 2012;344:e3651

๑ BMJ Publishing Group Ltd 2012 